\title{
FORMULATION AND EVALUATION OF GRANULE OF CRUDE BROMELAIN OF PINEAPPLE (Ananas comosus (L.) Merr) CROWN OF SUBANG DISTRICT, INDONESIA
}

\author{
N. M. Saptarini ${ }^{\bowtie}$ and D. Rahayu \\ Department of Pharmaceutical Analysis and Medicinal Chemistry, Faculty of Pharmacy, \\ Universitas Padjadjaran, Jatinangor-45363, West Java, Indonesia \\ ${ }^{\circledR}$ Corresponding Author: nyi.mekar@unpad.ac.id
}

\begin{abstract}
The crown of pineapple (Ananas comosus (L.) Merr) of Subang district, Indonesia, is proven to contain bromelain, which has been characterized and has protease and antioxidant activity. These findings show that crude bromelain has the potential to be developed into herbal preparations. The purpose of this study was to formulate and evaluate crude bromelain granules from the pineapple crown of Subang district, Indonesia. Granule was chosen, due to the advantages, i.e. better flow properties, prevent constituent segregation, physical and chemically stability, and content uniformity. Crude bromelain was formulated by wet granulation with povidone as a binder. The granule was evaluated using compendial methods, i.e. moisture content, repose angle, bulk density, tapped density, Hausner's ratio and Carr's compressibility index. The evaluation results showed that crude bromelain granule met the requirements of good granules. The crude bromelain granule has protease activity of $7.73 \pm 0.12 \mathrm{IU} / \mathrm{mg}$ and antioxidant activity of $3516.67 \mu \mathrm{g} / \mathrm{ml}$. Crude bromelain can be formulated into granule with protease and antioxidant activity.

Keywords: Protease Activity, Antioxidant Activity, Povidone, Wet Granulation, Compedial Methods
\end{abstract}

RASĀYAN J. Chem., Vol. 14, No.2, 2021

\section{INTRODUCTION}

The pineapple (Ananas comosus (L.) Merr) which grown in several subtropical and tropical countries, including Indonesia, contains bromelain. Indonesia as a tropical country fulfills pineapple growing requirements. ${ }^{1}$ The main composition of bromelain is a proteolytic fraction of sulfhydryl. ${ }^{2}$ Bromelain has immunomodulatory activity ${ }^{3,4}$ and is used for the treatment of acute inflammation, sports injuries, and postoperative states. ${ }^{5}$ Its activities are suggested due to the protease acting on the cell surface proteins ${ }^{6-8}$ or soluble proteins. ${ }^{8}$

In this study, the pineapple was collected from Subang district, West Java, Indonesia, one of the pineapple production centers in Indonesia. ${ }^{9}$ In our previous studies, the pineapple crown from Subang district was proven to contain bromelain with a protease activity of $7.72 \pm 0.45 \mathrm{IU} / \mathrm{mg}^{10}$ with medium antioxidant activity ${ }^{11}$ and immunostimulant activity. ${ }^{12}$ These findings show that crude bromelain has the potential to be developed into herbal preparations. Granule was chosen, due to further processed into the capsule. Crude bormelain granule were formulated by wet granulation with povidone as a binder. The purpose of this study was to formulate and evaluate crude bromelain granule from the pineapple crown of Subang district, Indonesia.

\section{EXPERIMENTAL}

\section{Materials}

The 12 months old of pineapple fruits were collected from Subang district, West Java, Indonesia. The plant was identified by Plant Taxonomy Laboratory, Faculty of Mathematics and Natural Sciences, Universitas Padjadjaran, Indonesia with No. 517/HB/02/2019. All chemicals were analytical grade and purchased from Merck (Germany), i.e. ethanol, tyrosine, casein, trichloroacetic acid (TCA), and vitamin C, except 2,2-diphenyl-1-picryhydrazyl (DPPH) was purchased from Sigma Aldrich. All chemicals for granule formulation were pharmaceutical grade and purchased from B.S. Chemical (China), i.e. povidone, magnesium stearate, talc, and lactose monohydrate. 
RASĀYAN J. Chem.

Vol. 14 | No. 2 |1098-1104| April - June | 2021

\section{Bromelain Extraction}

The crowns were separated from the fruit, then washed and mashed with distilled water, then filtered. Ethanol was added to the filtrate, with a ratio of $1: 4$, then stored at $4 \pm 0.5^{\circ} \mathrm{C}$ for $8 \mathrm{~h}$. The precipitate was centrifuged for $15 \mathrm{~min}$ at $15,000 \mathrm{rpm}$. The sediment was dried at $30 \pm 0.5^{\circ} \mathrm{C} .{ }^{10}$

\section{Determination of Protease Activity of Crude Bromelain}

Five various concentrations of the tyrosine, as a product of protease activity, were measured at $275 \mathrm{~nm}$. The concentration and absorbance were plotted to determine the linearity of the calibration curve. The mixed of the casein solution $(1 \mathrm{mg} / \mathrm{ml})$ and the crude bromelain $(1 \mathrm{mg} / \mathrm{ml})$ were incubated for $30 \mathrm{~min}$. The TCA solution was added, then continued incubation for $5 \mathrm{~min}$ at $90 \pm 0.5{ }^{\circ} \mathrm{C}$, then cooled to room temperature. The absorbance was measured at $275 \mathrm{~nm} .{ }^{10}$ Protease activity was calculated by the eqn.-1. ${ }^{13}$

$\mathrm{IU} / \mathrm{mg}=\frac{\mu \mathrm{mol} \text { produced tyrosine }}{\mathrm{mg} \text { extract } \mathrm{x} \text { time }}$

\section{Determination of Antioxidant Activity of Crude Bromelain}

Five various concentrations of vitamin $C$ as standard and crude bromelain were added in $40 \mu \mathrm{g} / \mathrm{ml}$ of DPPH solution. The mixed solutions were incubated for $30 \mathrm{~min}$ in a dark chamber, then the absorbances were measured using a visible spectrophotometer at $517 \mathrm{~nm}$. The blank was $96 \%$ ethanol. Percentage scavenging activity was calculated using eqn.-2. Percent inhibition versus concentration was plotted to achieve linear regression, then calculated the concentration which required for $50 \%$ of inhibition and expressed as $\mathrm{IC}_{50}$ value. ${ }^{11}$

Percentage of Inhibition $=\left[\left(\mathrm{A}_{\mathrm{DPPH}}-\mathrm{A}_{\text {sample }}\right) / \mathrm{A}_{\mathrm{DPPH}}\right] \times 100 \%$

\section{Formulation of Crude Bromelain Granule}

Granule was formulated by wet granulation, which consists of crude bromelain, 3\% povidone, $1 \%$ magnesium stearate, $2 \%$ talc, and lactose monohydrate. The weight of crude bromelain was calculated from protease activity. Lactose monohydrate weight was calculated from 100\% substracte with all other constituents. All constituents were weighed and mixed until homogeneous. Ethanol was added to the mixture to produce a moist mass. The moist mass was sifted with $1.4 \mathrm{~mm}$ sieve, then dried at $40 \pm 0.5^{\circ} \mathrm{C}$ for $4 \mathrm{~h}$ in the dryer (Memmert INB500, Germany), and evaluated the physical properties. ${ }^{14}$

\section{Evaluation of Crude Bromelain Granule}

The granule was evaluated using compendial methods, i.e. moisture content, repose angle, bulk density, tapped density, Hausner's ratio and compressibility index.

\section{Moisture Content}

Granule was placed at a moisture analyzer (G-Won Hitech) at $105 \pm 0.5^{\circ} \mathrm{C}$ until constant weight $(\mathrm{n}=3) .^{15}$

\section{Repose Angle}

The repose angle $(\theta)$ was calculated with eqn.3 $(n=3)$. The stainless steel funnel was fixed in place, $4 \mathrm{~cm}$ above the bench surface. The height of the granules forming the cone (h) and the radius (r) of the cone base was measured from the granule. The valid result was achieved from a symmetrical granule cone. ${ }^{15}$

$\theta=\tan ^{-1}\left(\frac{h}{r}\right)$

\section{Bulk and Tapped Density}

Granule was weighed, then placed in a measuring cup and recorded the volume as bulk density. Tapped density was obtained by tapping a measuring cup containing granule as high as $2.5 \mathrm{~cm}$ with $2 \mathrm{sec}$ interval. Every 10 taps, the volume was recorded until the constant volume $(n=3){ }^{14,15}$ 
RASĀYAN J. Chem.

Vol. 14 | No. 2 |1098-1104| April - June | 2021

\section{Flow Character}

Hausner's ratio and compressibility index were used to determine the flow character. The bulk and tapped densities were used to calculate the Hausner's ratio with eqn. $-4^{16}$ and Carr's compressibility index with eqn. $5^{17}$ to provide a measure of the flow properties of granule $(n=3)$.

$$
\begin{aligned}
& \text { Hausner's Ratio }(\mathrm{HR})=\frac{\text { tapped density }}{\text { bulk density }} \\
& \text { Compressibility Index }(\mathrm{CI})=\frac{\text { tapped density -bulk density }}{\text { tapped density }} \times 100
\end{aligned}
$$

\section{Determination of Protease Activity of Crude Bromelain Granule}

This determination was carried out by the modified method of crude bromelain, i.e. centrifugation to separate insoluble components. The mixed of the casein solution $(1 \mathrm{mg} / \mathrm{ml})$ and the granule (equivalent to $1 \mathrm{mg} / \mathrm{ml}$ crude bromelain) were incubated for $30 \mathrm{~min}$. The TCA solution was added, then continued incubation for $5 \mathrm{~min}$ at $90 \pm 0.5^{\circ} \mathrm{C}$, and cooled to room temperature. The mixture was centrifuged at 4000 $\mathrm{rpm}$ for $15 \mathrm{~min}$. The absorbance was measured at $275 \mathrm{~nm} .{ }^{10}$ Protease activity was calculated by the eqn.$1 .{ }^{13}$

\section{Determination of Antioxidant Activity of Crude Bromelain Granule}

This determination was carried out by the modified method of crude bromelain, i.e. centrifugation to separate insoluble components. The granule was weighed equivalent to crude bromelain, then dissolved in distilled water and centrifuged at $4000 \mathrm{rpm}$ for $15 \mathrm{~min}$. These solutions were determined the antioxidant activity with the same method as crude bromelain. Antioxidant activity was calculated by the eqn.-2. ${ }^{11}$

\section{Statistical Analysis}

Data were shown as mean and standard deviation (SD). Data were statistically analyzed using a one-way analysis of variance. Data were considered to be significantly different if $p$-value $<0.05$.

\section{Bromelain Extraction}

\section{RESULTS AND DISCUSSION}

Subang district suitable for pineapple growth, due to its altitude is $0-1500 \mathrm{~m}$ above sea level. ${ }^{9,18}$ Pineapple aged 12 months was chosen, due to high bromelain is in the ripe fruit. Bromelain has globular shape, which dissolves in water and precipitate in ethanol as an organic solvent. ${ }^{19}$ Because of its property, so bromelain was isolated from the pineapple crown by ethanol precipitation. The hydrophobic interactions in the interior bromelain will be interfered by the organic solvents, but the covalent bonds in the peptide chain are stable. ${ }^{19}$ Other advantages of the precipitation method have concentrated the bromelain. There was $11.28 \mathrm{~kg}$ pineapple crown, which produces $28.21 \mathrm{~g}$ of crude bromelain and the yield was $0.25 \%$. This yield was similar to our previous studies, i.e. $0.23 \%{ }^{10}$ and $0.26 \%,{ }^{11}$ due to the same source and pineapple age. Crude bromelain was tasteless, light yellow powder, and slightly pineapple fragrance.

\section{Determination of Protease Activity of Crude Bromelain}

Tyrosine as the product of casein degradation was used to determine the protease activity of crude bromelain. The instrument response was proportional to the concentration, ${ }^{20}$ which showed by the correlation coefficient was 0.9989 (Fig.-1). Crude bromelain $(1 \mathrm{mg} / \mathrm{ml})$ degradated the casein as substrate, then tyrosine as the product measured by UV spectrophotometer at $275 \mathrm{~nm}$, due to the aromatic residue. ${ }^{21}$ The tyrosine absorbance from casein degradation of crude bromelain was $0.436 \pm 0.018$ which equivalent to $60.08 \pm 2.64 \mu \mathrm{g} / \mathrm{ml}$ of tyrosine. Protease activity was calculated by eqn.-1, so protease activity was $7.89 \pm 0.36 \mathrm{IU} / \mathrm{mg}$, which similar to our previous study, i.e. $7.72 \pm 0.45 \mathrm{IU} / \mathrm{mg} .{ }^{10}$ This showed the result consists of the crude bromelain of Subang pineapple crown.

\section{Determination of Antioxidant Activity of Crude Bromelain}

Our previous study showed that the maximum wavelength of DPPH solution was $517 \mathrm{~nm},{ }^{11}$ which according to the literature. ${ }^{22}$ The DPPH method is an easy, rapid, and sensitive method to determine the 
RASĀYAN J. Chem.

antioxidant activity of plant extracts. ${ }^{23}$ Vitamin $\mathrm{C}$ as a standard, used to determine the spectrophotometer's response to the vitamin $\mathrm{C}$ concentration. Linearity was observed from the correlation coefficient of 0.9998 (Table 1), which fulfills the requirement. ${ }^{20}$ Vitamin $\mathrm{C}$ showed a strong antioxidant activity with $\mathrm{IC}_{50}$ value of $5.73 \mu \mathrm{g} / \mathrm{ml}$. Crude bromelain showed medium antioxidant activity with $\mathrm{IC}_{50}$ value of $3319.49 \mu \mathrm{g} / \mathrm{ml}$ (Table 1). This value was smaller than our previous study, i.e. $3624 \mu \mathrm{g} / \mathrm{ml},{ }^{11}$ showed better antioxidant activity. There was an increased significant of $9.17 \%\left(p=9.48 \times 10^{-4}\right)$. It was assumed that crude bromelain was less non-protein content, although the yield was smaller, but the antioxidant activity was higher. These findings encouraged the usage of crude bromelain for herbal preparations.

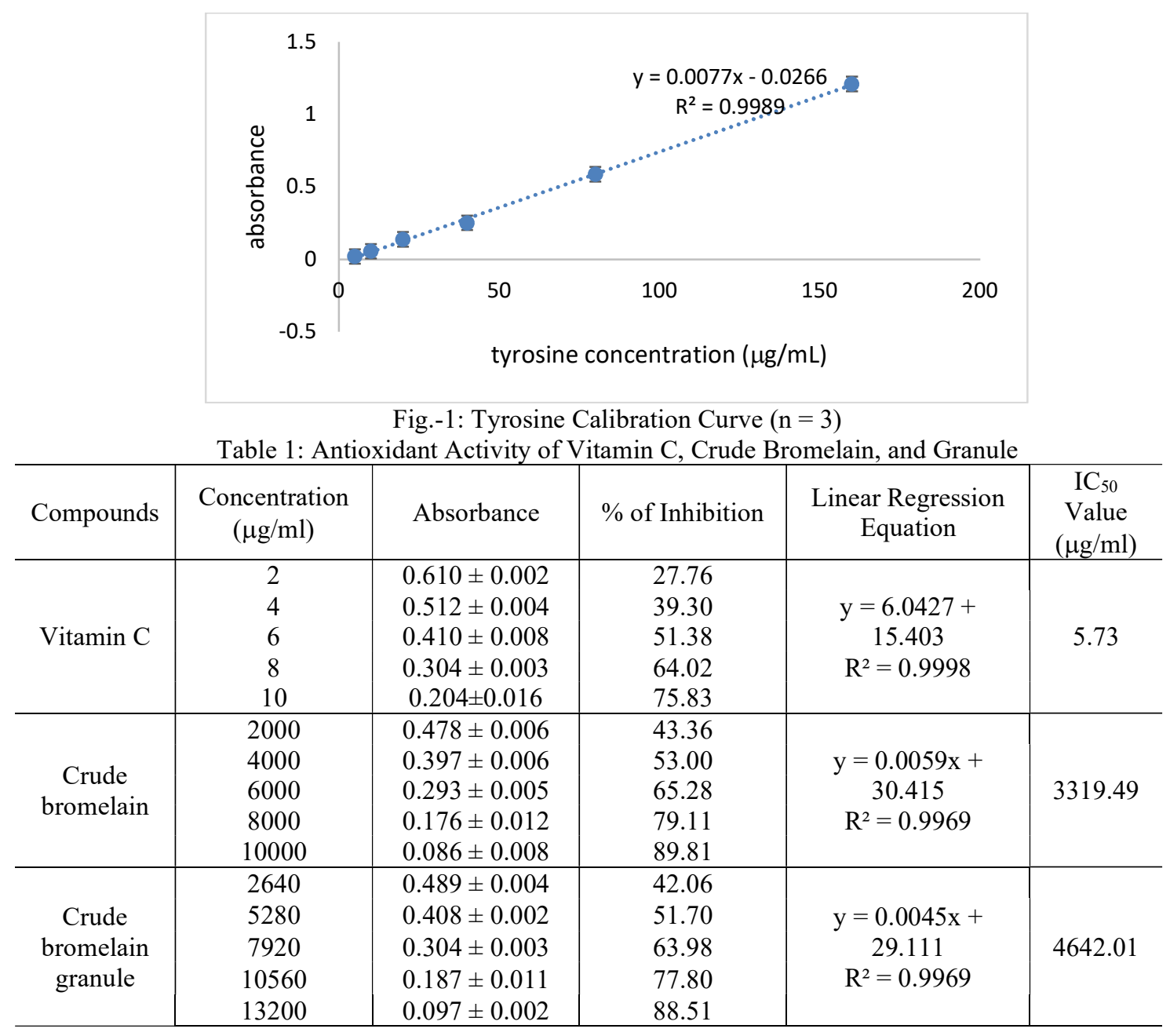

\section{Formulation of Crude Bromelain Granule}

The granule was chosen, due to further processed into the capsule. The advantages of granule compared to powder are better flow properties, prevent constituent segregation, physically and chemically stability, due to smaller surface area, and particle-size uniformity, thus content uniformity. ${ }^{14}$ Our previous study showed that crude bromelain of Subang pineapple crown has immunomodulatory activity. Bromelain has immunomodulatory activity at a dose of $3000 \mathrm{IU} .{ }^{24} \mathrm{In}$ this study, $6000 \mathrm{IU} / \mathrm{g}$ of crude bromelain granule was formulated, thus $500 \mathrm{mg}$ of capsule can be made with a dose of $3000 \mathrm{IU}$ of crude bromelain. Protease activity was $7.89 \pm 0.36 \mathrm{IU} / \mathrm{mg}$, then to achieve the protease activity of $6000 \mathrm{IU} / \mathrm{g}$ required $760 \mathrm{mg}$ of crude bromelain in each gram of granule, i.e. $76 \%$. Granule formula after calculating the concentration of crude bromelain was $76 \%$ crude bromelain, $3 \%$ povidone, $1 \%$ magnesium stearate, $2 \%$ talc, and $18 \%$ 
lactose monohydrate. The percentage of constituents in granule is in the range according to the handbook of the excipients. Crude bromelain granule was light yellow with pineapple fragrant.

Magnesium stearate is a lubricant at concentrations between $0.25 \%$ and $5.0 \% .{ }^{25}$ It is a cohesive material, which prevents dust powder during filling, improves wall friction, and improves flow properties. ${ }^{26}$ Povidone is a binder, ${ }^{27}$ which added to the mixed powder in the dry form and granulated in situ by the addition of alcohol ${ }^{28}$ at concentrations between $0.5 \%$ and $5.0 \% \cdot{ }^{29}$ Povidone as a dry binder ensures that granule has required mechanical strength. ${ }^{29}$ Talc is a glidant and lubricant at concentrations between $1 \%$ and $10 \%$. Talc as a glidant will reduce interparticle friction and cohesion, thus promote granule flow. ${ }^{30}$ Talc as lubricant cause decreased disintegration time with increased granule size ${ }^{31}$ Lactose monohydrate is a diluent and filler to produce and convenient dosage form. Lactose is inert, compatible, nonhygroscopic, and tasteless. ${ }^{32}$

Crude bromelain granule was constituents agglomerate prepared into larger and free-flowing particles with irregular shape. The granule flow is a key requirement for the manufacturing process, due to determine similar volume filling of granules in capsule manufacturing. ${ }^{26}$ Evaluation of crude bromelain granule was physical properties of granule based on compendial methods. The moisture content of granule met the granule requirement, i.e. $4.1 \pm 0.2 \% .{ }^{33}$ Cohesion and adhesion risk will be increased with increasing moisture content. The repose angle described flowability. ${ }^{15}$ Crude bromelain granule has a repose angle of $25.17 \pm 0.32^{\circ}$. This value showed that 'excellent' flow, due to less than $30^{\circ} .{ }^{15}$ Bulk and tapped density of granule were $0.68 \pm 0.22 \mathrm{~g} / \mathrm{ml}$ and $0.76 \pm 0.14 \mathrm{~g} / \mathrm{ml}$, respectively. This closer in value showed a free-flowing granule with less inter-particulate interactions. ${ }^{14} \mathrm{HR}$ is a measure of the inter particulate friction ${ }^{16}$ and $\mathrm{CI}$ is a measure of powder bridge strength and stability. ${ }^{17}$ The flowing character is rated based on the $\mathrm{HR}^{16}$ and compressibility index. ${ }^{17}$ Crude bromelain granule has $\mathrm{HR}$ and CI was 1.22 \pm 0.14 and $17.86 \pm 0.21 \%$, respectively. These values indicate granule has 'fair' flow character, due to in the range 1.19-1.25 and 16-20\%, respectively. Good flow properties have low HR or low CI. ${ }^{16,17}$ The bulk density, tap density, HR, and CI used to determine the granule flowability, thus the problems related to flow properties can be avoided by taking the prevention. ${ }^{14}$ These parameters help to maintain the uniform granules flow to ensure precise capsule weight and drug content. All parameters showed that crude bromelain granule met the requirements of a good granule.

\section{Determination of Protease Activity of Crude Bromelain Granule}

Granule contains $76 \%$ crude bromelain, then the protease activity assay was carried out at $1.32 \pm 0.04 \mathrm{mg}$ of granule containing $1 \mathrm{mg}$ of crude bromelain. Tyrosine absorbance from casein degradation of protease activity of crude bromelain granule was $0.427 \pm 0.029$, which equivalent to $58.83 \pm 1.83 \mathrm{mg} / \mathrm{ml}$ of tyrosine. Protease activity was calculated by eqn.-1, so protease activity was $7.73 \pm 0.12 \mathrm{IU} / \mathrm{mg}$. This result showed statistically significant $(p=0.0019)$ between crude bromelain and crude bromelain granule. The granule formula causes a decreased protease activity of $2.03 \pm 0.35 \%$. This was assumed because crude bromelain bound to the binder and dissolved incompletely. Protease activity still meets the requirements, due to its activity was $97.97 \pm 0.32 \%$. Monographs of pharmaceutical preparation state the active ingredient content is $90-110 \%$ of stated on the package. ${ }^{15}$ It's concluded that crude bromelain can be formulated into 'good' granule with $97.97 \pm 0.32 \%$ of protease activity.

\section{Determination of Antioxidant Activity of Crude Bromelain Granule}

Granule contains $76 \%$ crude bromelain, then antioxidant activity assays were carried out at 1.32 times the crude bromelain weight (Table 1). The $\mathrm{IC}_{50}$ value of crude bromelain granule of $4642.01 \mu \mathrm{g} / \mathrm{ml}$ (Table 1), which is equivalent to $3516.67 \mu \mathrm{g} / \mathrm{ml}$ of crude bromelain. There was a decreased antioxidant activity by $5.61 \%$, which statistically significant $\left(p=7.18 \times 10^{-3}\right)$. It was assumed because the crude bromelain bound to the binder and dissolves incompletely.

\section{CONCLUSION}

Crude bromelain can be formulated into granule with protease and antioxidant activity. Crude bromelain granule met the requirements of good granules. 
RASĀYAN J. Chem.

Vol. 14 | No. 2 |1098-1104| April - June | 2021

\section{ACKNOWLEDGMENT}

The authors would like to thank Siti Nurjanah and Irma Erika Herawati for their technical assistance. The authors also would like to thank Kemenristek Dikti Grants in 2020 with contract number 1827/UN6.3.1/LT/2020 for the financial support.

\section{REFERENCES}

1. S. Mondal, S. Bhattacharya, J.N. Pandey and M. Biswas, Pharmocologyonline, 3, 1312(2011).

2. L.P. Hale, P.K. Gree, C.T. Trinh and C.L. James, International Immunopharmacology, 5, 783(2005), DOI:10.1016/j.intimp.2004.12.007

3. L.P. Hale, International Immunopharmacology, 4, 255(2004), DOI:10.1016/j.intimp.2003.12.010

4. F.H. Sarkar and Y. Li, Mutation Research, 555, 53(2004), DOI:10.1016/j.mrfmmm.2004.04.015

5. G. Yuan, M.L. Wahlqvist, G. He, M. Yang and D. Li, Asia Pacific Journal of Clinical Nutrition, 15, 143(2006).

6. T.L. Mynott, A. Ladhams, P. Scarmato and C.R. Engwerda, Journal of Immunology, 163, 2568(1999).

7. C.R. Engwerda, D. Andrew, M. Murphy and T.L. Mynott, Cell Immunology, 210, 5(2001), DOI: $10.1006 / \mathrm{cimm} .2001 .1793$

8. H. Barth, A. Guseo and R. Klein, European Journal of Medical Research, 10, 325(2005).

9. http://subang.go.id/profil/letak-geografis

10. N.M. Saptarini, D. Rahayu and S.A.F. Kusuma, Rasayan Journal of Chemistry 12(4), 2074(2019), DOI:10.31788/RJC.2019.1245132

11. N.M. Saptarini and D. Rahayu, Journal of Pharmaceutical Bioallied Sciences, 11(Suppl S4), 551(2019), DOI:10.4103/jpbs.JPBS_200_19

12. N.M. Saptarini, D. Rahayu and E. Kartikawati, Research Journal of Pharmacy and Technology, 13(11), 5177(2020), DOI:10.5958/0974-360X.2020.00905.1

13. V.A. Tamhane, N.P. Chougule, A.P. Giri, A.R. Dixit, M.N. Sainani and V.S. Gupta, Biochimica Et Biophysica Acta: General Subjects, 1722(2), 156(2005), DOI:10.1016/j.bbagen.2004.12.017

14. F.J. Bandelin and R.F. Shangraw, 1989, Compressed Tablet by Wet Granulation, in: H.A. Lieberman, L. Lachman and J.B. Schwartz (Eds.), Pharmaceutical Dosage Forms, Vol.1, Marcel Dekker Inc, USA, pp. 148-52.

15. The United States Pharmacopeial Convention. US Pharmacopeia. 32th ed, Rockville MD, USA (2008).

16. H.H. Hausner, International Journal of Powder Metallurgy, 3, 7(1967).

17. R.L. Carr, Chemical Engineering, 72, 69(1965).

18. O.V. Omotoyinbo and D.M. Sanni, American Journal of Biology Sciences, 5(3), 35(2017), DOI:10.11648/j.ajbio.20170503.11

19. D.L. Nelson and M.M. Cox, Lehninger: Principles of Biochemistry, $5^{\text {th }}$ ed, W.H. Freeman, USA, pp. 89-96(2008).

20. http://www.fda.gov/downloads/drugs/guidancecomplianceregulatoryinformation/guidances/ucm0733 84.pdf

21. J.R. Whitaker, 1996, Enzymes, in: O.R. Fennema (Ed.), Food Chemistry, $3^{\text {rd }}$ ed, Marcel Dekker Inc, New York, pp. 82-95.

22. P. Molyneux, Songklanakarin Journal of Science and Technology, 26(2), 211(2004).

23. I.I. Koleva, T.A. van-Beek, J.P.H. Linssen, A. de Groot and L.N. Evstatieva, Phytochemistry Analysis, 1, 8(2002), DOI:10.1002/pca.611

24. S. Muller, R. Marz, M. Schmolz, B. Drewelow, K. Eschmann and P. Meiser, Phytotherapy Research, 27(2), 199(2013), DOI: 10.1002/ptr.4678

25. L.V. Allen Jr and P.E. Luner, 2009, Magnesium stearate, in: R.C. Rowe, P.J. Sheskey and M.E. Quinn (Eds), Handbook of Pharmaceutical Excipients, 6th ed, Pharmaceutical Press and American Pharmacists Assoc, Washington, pp. 404-408. 
RASĀYAN J. Chem.

Vol. 14 | No. 2 |1098-1104| April - June | 2021

26. R.B. Shah, M.A. Tawakkul and M.A. Khan, AAPS PharmSciTech, 9(1), 250(2008), DOI:10.1208/s12249-008-9046-8

27. D. Becker, T. Rigassi and A. Bauer-Brandl, Drug Development and Industrial Pharmacy, 23(8), 791(1997), DOI: 10.3109/03639049709150550

28. M. Iwata and H. Ueda, Drug Development and Industrial Pharmacy, 22, 1161(1996), DOI: $10.3109 / 03639049609065953$

29. A.H. Kibbe, Povidone, 2009, in: Rowe RC, Sheskey PJ, Quinn ME, editors. Handbook of Pharmaceutical Excipients. 6th ed. Pharmaceutical Press and American Pharmacists Assoc, Washington, pp. 581-585.

30. A.H. Kibbe, 2009, Talc, in: R.C. Rowe, P.J. Sheskey and M.E. Quinn (Eds), Handbook of Pharmaceutical Excipients, 6th ed, Pharmaceutical Press and American Pharmacists Assoc, Washington, pp. 728-731.

31. K.T. Jaiyeobaa and O.O. Oladiran, Drug Development and Industrial Pharmacy, 9(1), 267(1983).

32. S. Edge, A.H. Kibbe and J. Shur, 2009, Lactose monohydrate, in: R.C. Rowe, P.J. Sheskey and M.E. Quinn (Eds), Handbook of Pharmaceutical Excipients, 6th ed, Pharmaceutical Press and American Pharmacists Assoc, Washington, pp. 364-369.

33. M.E. Aulthon, Pharmaceutics the Science of Dosage Form Design, Longman Group, New York, p. 295-304(2002).

[RJC-6300/2020] 